\title{
ENDOMETRIOSIS-ASSOCIATED INFERTILITY: THE ROLE OF HORMONES AND ITS CORRECTION
}

\section{*I.I. Kulyk, S.V. Khmil \\ I. HORBACHEVSKY TERNOPIL NATIONAL MEDICAL UNIVERSITY, TERNOPIL, UKRAINE}

Background. Endometriosis-associated infertility (EAI) has a number of specific features, which are crucial in the choice of medical treatment.

Objective. The aim of the study is to analyze endocrine profile in women with EAI before and after sclerotherapy and pregravid preparation (PP), which includes a vitamin complex FT 500 plus with inositol and vitamin D3.

Methods. The study involved 70 women aged 21-40 years with endometriosis-associated infertility. The comparison group included 30 women with tuboperitoneal infertility. ELISA was used to determine concentrations of Anti-Mullerian hormone (AMH), follicle stimulating hormone (FSH), luteinizing hormone (LH), progesterone and estradiol in blood serum using a standard kit by Diagnostic Systems Laboratories, Inc (USA). During two menstrual cycles the FT 500 plus was prescribed once a day from the $2^{\text {nd }} / 3^{r d}$ day of the cycle, vitamin D3 was prescribed at the dose of 2,000 IU for women without its deficiency and in therapeutic doses in case of hypovitaminosis. The sclerotherapy with 95\% ethanol solution was performed on the $6^{\text {th }}$ - ${ }^{\text {th }}$ day of menstrual cycle.

Results. It was established that in women with EAI undergoing PP and sclerotherapy the level of AMH was lower (by 12.90\%) as well as progesterone (by 9.84\%), while FSH (by 14.47\%), LH (by 21.14\%) and estradiol (by $35.55 \%$ ) was higher compare to the comparison group. At the same time, FSH (by 21.98\%), LH (by 32.89\%) and estradiol (by 32.23\%) concentrations were significantly lower compare to their primary indices before sclerotherapy.

Conclusions. Sclerotherapy and PP with a vitamin complex, inositol and vitamin D3 has a positive effect on endocrine profile in women with endometriosis-associated infertility

KEYWORDS: infertility; endometriosis; hormones; sclerotherapy; inositol; vitamin D3.

\section{Introduction}

Genital endometriosis is one of the most common diseases in women of reproductive age. It attracts attention of scientists and practitioners around the world. According to the literature, every tenth woman of reproductive age suffers from endometriosis that is 176 million women (World Population Projection Tables by Country and Group, 2010). The main symptoms of endometriosis are infertility, menorrhagia, dysmenorrhea, dyspareunia, chronic pelvic pain. In $20-25 \%$ of women, this disease is asymptomatic [1].

Endometriosis-associated infertility is characterized by a number of specific features that must be considered when choosing treatment methods. In each case, treatment should be individual, taking into account all clinical factors, as well as the impact of the disease and the effect of treatment on the quality of woman's life [2, 3].

*Corresponding author: Iryna Kulyk, PhD student, Department of Obstetrics and Gynecology, I. Horbachevsky Ternopil National Medical University, 1 Maidan Voli, Ternopil, 46001 Ukraine.Email: kulyk_iryna1@ukr.net
The classic surgical treatment of endometriosis is necessary in cases of cyst capsule; according to the literature, it facilitates the lowest number of recurrences and the highest number of clinical pregnancies [4-7]. However, it should be taken into account that besides the capsule, a significant part of healthy ovarian tissue with antral follicles is removed [8]. Therefore, the search for less traumatic and more effective treatment, i.e. puncture of endometriomas and sclerotherapy, is carried on [9].

To date, the choice of treatment for women with endometriosis-associated infertility for assisted reproductive technology (ART) programs is still controversial. According to evidencebased medicine it is established that in women with endometriosis-associated infertility, the balance between intracellular trace elements is disturbed; free radical oxidation processes are activated, which leads to oxidative stress, which consecutively may disturb the effectiveness of ART. Reactive oxygen species are usually significant in a number of reproductive tract functions, but their overproduction has a negative effect on estrogen levels, altering 
steroidogenesis, thereby preventing oocyte maturation and ovulation $[10,11]$. Therefore, we consider using antioxidants during pregravid preparation of patients with endometriosisassociated infertility before COS protocol reasonable.

The aim of the study was to analyze concentrations of the reproductive hormones in women with endometriosis-associated infertility before and after sclerotherapy and pregravid preparation with a complex vitamin medication comprising inositol and vitamin D3.

\section{Methods}

The study involved 70 women aged 21-40 years with endometriosis-associated infertility, who were treated in the Medical Center "Clinic of Professor Stefan Khmil" in 2015-2020. The comparison group included 30 women of the same age with tuboperitoneal infertility, diagnosed by laparoscopy or echosalpingography. Exclusion criteria were for patients with endometriosis, stage 3-4, polycystic ovary syndrome, uterine fibroids (submucosal, symptomatic subserosal or intramural with a diameter of more than $2 \mathrm{~cm}$ ), who were not included into the study groups. External genital endometriosis was verified by laparoscopy and confirmed by histopathological examination (endometrioid cyst of an ovary or both ovaries).

The patients with endometriosis-associated infertility were divided into 2 groups. Group 1 $(n=34)$ involved women of reproductive age (21-40 years old) with endometrioid cysts of up to $6.5 \mathrm{~cm}$ in diameter, who underwent sclerotherapy and pregravid preparation with a complex vitamin medication comprising inositol and vitamin D3; group $2(n=36)$ comprised women, who underwent sclerotherapy. The presence of cysts was confirmed by ultrasound and bimanual examination.

Determination of hormone indicators was performed in different phases of the cycle before and after sclerotherapy and pregravid treatment. Determination of concentrations of reproductive hormones was performed in the certified laboratory of the Medical Center "Clinic of Professor Stefan Khmil". ELISA was used to determine the concentrations of Anti-Mullerian hormone $(\mathrm{AMH})$, follicle stimulating hormone (FSH), luteinizing hormone (LH), progesterone and estradiol (E2) in blood serum according to manufacturer's instructions using a standard set of reagents provided by Diagnostic Systems Laboratories, Inc. (USA), by means of the StatFax analyzer.
The vitamin complex FT 500 plus for women of group 1 was prescribed at the dose of 1 sachet once a day from the $2^{\text {nd }}$ or $3^{\text {rd }}$ day of the cycle, after taking blood test for hormones, i.e. $\mathrm{AMH}, \mathrm{FSH}$ and $\mathrm{LH}$, during 2 menstrual cycles (cycle in which sclerotherapy was performed and subsequent cycle). Vitamin D3 was prescribed at prophylactic doses of 2,000 IU to those patients who were not diagnosed with a deficiency of this vitamin and at medium therapeutic doses in cases of hypovitaminosis during 2 menstrual cycles.

The procedure of sclerotherapy was performed in a sterile surgery room with or without general anesthesia on the $6^{\text {th }}-8^{\text {th }}$ day of the menstrual cycle by transvaginal puncture of the cyst and aspiration of its contents under the control of transvaginal ultrasound, introduction of sclerosing solution into the cyst capsule (without violating its integrity). $76 \%$ ethanol solution was used as a sclerosant installed in a volume of $50 \%-90 \%$ of the cyst size under ultrasound control with its subsequent aspiration.

Statistical analysis of the results was performed using Microsoft Office Excel and Statistica 7.0 software. The choice of the data analysis method was based on the number of the groups, their distribution, as well as the equality of variances. All data were verified by the one sample Kolmogorov-Smirnov test to confirm normality. Abnormal distribution data was analyzed by a nonparametric test (the Mann-Whitney $U$ test and the Kruskal-Wallis test). The indicators with abnormal distribution were defined as Me (Q25; Q75) (medians and Q25 and Q75 quartiles). The biochemical findings were analyzed by repeated non-parametric ANOVA test for multiple comparisons. A probability level of less than 0.05 was considered to be statistically significant.

\section{Results}

Study of the reproductive hormones of the women with endometriosis-associated infertility proved a significantly lower level of Anti-Mullerian hormone $(\mathrm{AMH})$ in women before and after sclerotherapy compare to the comparison group. It was established that sclerotherapy in women with endometriosis-associated infertility caused a decrease of FSH by $20.31 \%$ compare to the indices before the therapy for endometriomas but was still statistically significantly higher compare to the comparison group (by 20.75\%).

Also, a decrease of the $\mathrm{LH}$ concentration by $16.96 \%$ was evidenced in the patients after 
sclerotherapy compare to the indices before the therapy for endometriomas. It was statistically significantly higher than those of the comparison group (by $39.02 \%$ ). The level of estradiol in blood serum of the women with endometriosis-associated infertility after sclerotherapy was significantly lower by $26.63 \%$ compared to that before surgery, but was still significantly higher compare to the comparison group (by $41.11 \%$ ). Similar changes were observed for progesterone levels on the $19^{\text {th }}-21^{\text {st }}$ day of menstrual cycle (d.m.c.) in blood serum of the women with endometriosis-associated infertility after sclerotherapy; specifically, it increased by $14.94 \%$ compare to the indices before sclerotherapy, but was by $25.11 \%$ lower compare to the comparison group. Please note that sclerotherapy did not affect the level of prolactin (Table 1).

The women with endometriosis-associated infertility, who underwent pregravid preparation with a complex vitamin medication comprising inositol and vitamin D3 as well as sclerotherapy had significantly lower levels of AMH (by $12.90 \%$ ), progesterone (by $9.84 \%$ ) and significantly higher levels of FSH (by $14.47 \%$ ), LH (by $21.14 \%$ ) estradiol (by $35.55 \%$ ) compare to the comparison group. At the same time, significantly lower levels of FSH (by $21.98 \%$ ), LH (by $32.89 \%$ ) and estradiol (by $32.23 \%$ ) were evidenced compare to those before sclerotherapy (Table 2).

Table 1. Concentration of reproductive hormones in the women with endometriosis-associated infertility before and after sclerotherapy and no pregravid preparation (Me (Q25; Q75))

\begin{tabular}{|c|c|c|c|}
\hline Indicators & $\begin{array}{c}\text { Comparison group } \\
(\mathrm{n}=30)\end{array}$ & $\begin{array}{l}\text { Before sclerotherapy } \\
\qquad(\mathrm{n}=36)\end{array}$ & $\begin{array}{l}\text { After sclerotherapy } \\
(\mathrm{n}=36)\end{array}$ \\
\hline $\mathrm{AMH}, \mathrm{pmoL} / \mathrm{L}$ & $\begin{array}{c}1.75 \\
(1.56 ; 1.92)\end{array}$ & $\begin{array}{c}1.50 * \\
(1.30 ; 1.73)\end{array}$ & $\begin{array}{c}1.50 * \\
(1.30 ; 1.73)\end{array}$ \\
\hline $\mathrm{FSH}, \mathrm{IU} / \mathrm{L}$ & $\begin{array}{c}7.95 \\
(6.93 ; 8.50)\end{array}$ & $\begin{array}{c}11.55^{\star} \\
(10.90 ; 12.43)\end{array}$ & $\begin{array}{c}9.60 * \\
(8.78 ; 10.60)\end{array}$ \\
\hline $\mathrm{LH}, \mathrm{IU} / \mathrm{L}$ & $\begin{array}{c}6.15 \\
(5.45 ; 6.80)\end{array}$ & $\begin{array}{c}10.00 * \\
(9.30 ; 10.70)\end{array}$ & $\begin{array}{c}8.55^{\star} \\
(7.98 ; 9.23)\end{array}$ \\
\hline $\begin{array}{l}\text { Estradiol on the } 2^{\text {nd }}-3^{\text {rd }} \text { d.m.c., } \\
\mathrm{pmoL} / \mathrm{L}\end{array}$ & $\begin{array}{c}36.85 \\
(33.70 ; 40.08) \\
\end{array}$ & $\begin{array}{c}65.85^{*} \\
(60.40 ; 73.90) \\
\end{array}$ & $\begin{array}{c}52.00 * \\
(48.63 ; 55.53) \\
\end{array}$ \\
\hline $\begin{array}{l}\text { Progesterone on the } 19^{\text {th }}-21^{\text {st }} \text { d.m.c. } \\
\mathrm{nmol} / \mathrm{L}\end{array}$ & $\begin{array}{c}13.95 \\
(12.63 ; 15.58)\end{array}$ & $\begin{array}{c}9.70 * \\
(8.18 ; 11.43)\end{array}$ & $\begin{array}{c}11.15^{\star} \\
(9.63 ; 12.23)\end{array}$ \\
\hline Prolactin, ng/mL & $\begin{array}{c}10.95 \\
(10.40 ; 12.28)\end{array}$ & $\begin{array}{c}10.40 \\
(9.60 ; 11.40)\end{array}$ & $\begin{array}{c}10.30 \\
(9.50 ; 11.08)\end{array}$ \\
\hline
\end{tabular}

Notes. Statistically significant difference $(p<0.05)$ compared to: * - the comparison group. Me (Q25; Q75) (median, Q25 and Q75 quartiles).

Table 2. Concentration of reproductive hormones in the women with endometriosis-associated infertility before and after sclerotherapy, who underwent pregravid preparation with a complex vitamin medication comprising inositol and vitamin D3 (Me (Q25; Q75))

\begin{tabular}{|c|c|c|c|}
\hline Indicators & $\begin{array}{c}\text { Comparison group } \\
(\mathrm{n}=30)\end{array}$ & $\begin{array}{l}\text { Before sclerotherapy } \\
\qquad(\mathrm{n}=34)\end{array}$ & $\begin{array}{l}\text { After sclerotherapy } \\
(\mathrm{n}=34)\end{array}$ \\
\hline $\mathrm{AMH}, \mathrm{pmoL} / \mathrm{L}$ & $\begin{array}{c}1.75 \\
(1.56 ; 1,92)\end{array}$ & $\begin{array}{c}1.55^{\star} \\
(1.40 ; 1.78)\end{array}$ & $\begin{array}{c}1.50^{*} \\
(1.30 ; 1.80)\end{array}$ \\
\hline $\mathrm{FSH}, \mathrm{IU} / \mathrm{L}$ & $\begin{array}{c}7.95 \\
(6.93 ; 8.50)\end{array}$ & $\begin{array}{c}11.10^{\star} \\
(10.50 ; 12.40)\end{array}$ & $\begin{array}{c}9.10 * \\
(8.30 ; 9.88)\end{array}$ \\
\hline $\mathrm{LH}, \mathrm{IU} / \mathrm{L}$ & $\begin{array}{c}6,15 \\
(5.45 ; 6.80)\end{array}$ & $\begin{array}{c}9.90 * \\
(8.65 ; 11.00)\end{array}$ & $\begin{array}{c}7.45 * \# \\
(6.93 ; 8.65)\end{array}$ \\
\hline $\begin{array}{l}\text { Estradiol on the } 2^{\text {nd }}-3^{\text {rd }} \text { d.m.c., } \\
\mathrm{pmoL} / \mathrm{L}\end{array}$ & $\begin{array}{c}36.85 \\
(33.70 ; 40.08)\end{array}$ & $\begin{array}{c}66.05^{\star} \\
(61.50 ; 74.10)\end{array}$ & $\begin{array}{c}49.95^{*} \\
(43.73 ; 55.38)\end{array}$ \\
\hline $\begin{array}{l}\text { Progesterone on the } 19^{\text {th }}-21^{\text {st }} \text { d.m.c. } \\
\mathrm{nmol} / \mathrm{L}\end{array}$ & $\begin{array}{c}13.95 \\
(12.63 ; 15.58)\end{array}$ & $\begin{array}{c}10,45^{*} \\
(8.95 ; 12.48)\end{array}$ & $\begin{array}{c}12.70 * \# \\
(11.13 ; 13.50)\end{array}$ \\
\hline Prolactin, ng/mL & $\begin{array}{c}10.95 \\
(10.40 ; 12.28)\end{array}$ & $\begin{array}{c}11.00 \\
(9.53 ; 12.18)\end{array}$ & $\begin{array}{c}10.80 \\
(10.00 ; 12.00)\end{array}$ \\
\hline
\end{tabular}

Note. Statistically significant difference $(p<0.05)$ compared to: * the comparison group, \# - data before sclerotherapy. Me (Q25; Q75) (median, Q25 and Q75 quartiles). 
In order to compare the data, we analyzed the effect of pregravid preparation on the concentration of reproductive hormones in women with endometriosis-associated infertility after sclerotherapy, so the value of hormones before this surgical manipulation, we considered $100 \%$. It was found that the use of a complex vitamin medication comprising inositol, as well as vitamin D3 caused a decrease of LH level (by $10.25 \%)$, as well as an increase of progesterone level (by $6.58 \%$ ).

\section{Discussion}

The results of the study proved a positive effect of sclerotherapy on the endocrine profile of women with endometriosis-associated infertility. According to the literature, sclerotherapy of endometriomas is recommended for women with recurrent endometrioid cysts [12] to preserve the ovarian reserve avoiding surgical excision [13]. It was established that the recurrence rate after sclerotherapy ranged from $12.9 \%$ to $20 \%$ that almost did not differ from the indicators after laparoscopic cystectomy $[14,15]$.

It was found out that the number of antral follicles was increasing in the patients who underwent sclerotherapy for recurrent endometriomas $[16,17]$. The AMH blood level was an indirect marker of ovarian reserve. In our study, there were no significant changes in the $\mathrm{AMH}$ level in blood serum before and after sclerotherapy that is consistent with other studies [18]. Sclerotherapy can improve ovarian blood supply and follicle development [16], which consecutively may increase the probability of future fertility in the women undergoing sclerotherapy. The effect of sclerotherapy on the reproductive hormones level is still doubtful. Thus, Wang Xiaotao et al. established decreased levels of E2, FSH and LH [19]. In a study of Saeed Alborzi et al., the effect of sclerotherapy was associated with ovarian activity; in particular, a decrease of the FSH level as well as an increase of the AMH level and antral follicles [20]. On the other hand, Aflatoonian A et al. did not prove any significant difference between the studied hormones (FSH, LH) before and after sclerotherapy. The difference of the results may be due to different sizes of cysts in the studied female patients (our study involved women with endometrioid cysts of up to $6.5 \mathrm{~cm}$ in diameter), presence of cystectomy in medical history, localization (unilateral or bilateral endometrioma), and recurrence of endometrioid cysts.

Pregravid preparation with a complex vitamin medication comprising inositol and vitamin D3 had an effect. Inositol is a component of phospholipids and is a part of the cytoplasmic membranes as a phosphoinositide. Inositol binds $\mathrm{Ca}^{2+}$ channels and stimulates intracellular release of $\mathrm{Ca}^{2+}$. Increased intracellular $\mathrm{Ca}^{2+}$ level is significant for oocyte maturation, fertilization, and embryonic development. A sufficient concentration of inositol in the follicular fluid reduces the free radicals' level and membrane protein damage and increases the number of good quality oocytes [21]. 1.25-dihydroxyvitamin-D3 (vitamin D), except calcium-phosphate homeostasis, has a significant immunomodulatory effect (affects the local immune environment in an autocrine/paracrine way), affects the processes of cell proliferation and differentiation. Studies have shown that vitamin $D$ reduces concentration of anti-inflammatory cytokines: IL-6, interferon-g, IL-2, and TNF-a [21]. The combination of vitamin D3 multivitamin complex comprising inositol leads to normal ovarian activity, improves metabolic and hormonal profile, in particular, controls increased level of luteinizing hormone and oxidative stress [22].

\section{Conclusions}

Sclerotherapy and pregravid preparation with a complex vitamin medication comprising inositol and vitamin D3 has a positive effect on the endocrine profile in women with endometriosis-associated infertility.

\section{Conflicts of Interest}

Authors declare no conflict of interest.

\section{Authors' Contributions}

Iryna Kulyk-investigation, conceptualization, data curation, formal analysis, writing - original draft.

Stefan Khmil - data curation, writing reviewing and editing. 


\title{
ОСОБЛИВОСТІ ГОРМОНАЛЬНОГО ФОНУ ЖІНОК 3 БЕЗПЛІДДЯМ НА ФОНІ ЕНДОМЕТРІОЗУ ТА МЕТОДИ ЇХ КОРЕКЦІї
}

\author{
I.I. Кулик, С.В. Хміль \\ ТЕРНОПІЛЬСЬКИЙ НАЦІОНАЛЬНИЙ МЕДИЧНИЙ УНІВЕРСИТЕТ IМЕНІ І.Я. ГОРБАЧЕВСЬКОГО, \\ ТЕРНОПІЛЬ, УКРАЇНА
}

Вступ. Безпліддя на фоні генітального ендометріозу характеризується низкою специфічних особливостей, які необхідно врахувати при виборі методів лікування.

Мета дослідження - проаналізувати концентрацію гормонів репродуктивної системи у жінок 3 безпліддям на фоні ендометріозу до та після склеротерапії із застосуванням прегравідарної підготовки комплексним вітамінним препаратом з інозитолом та вітаміном D3.

Методи дослідження. У дослідження увійшло 70 жінок віком від 21 до 40 років з ендометріозасоційованим безпліддям та 30 жінок з трубно-перитонеальним фактором, як група порівняння. Визначення концентрації гормонів (антимюллерового гормону (АМГ), фолоікулостимулюючого гормону (ФСГ, лютеїнізуючий гормон (ЛГ), прогестерон та естрадіол) проводили за допомогою ІФА з використанням наборів «Diagnostic Systems Laboratories, Inc.» (США) на аналізаторі «StatFax».

Препарат FT 500 plus для жінок 1групи призначали в дозуванні 1 саше - 1 раз в день з 2-го або 3-го дня циклу протягом 2-х менструальних циклів (цикл у якому проводилась склеро терапія та наступний цикл). Вітамін D3 призначався у профілактичних дозах 2000 ОД жінкам, у яких не було діагностовано дефіциту даного вітаміну та в середньотерапевтичних дозах при гіповітамінозі протягом 2-х менструальних циклів. Процедура склеротерапії проводилась в умовах стерильної операційної на 6-8-й день менструального циклу шляхом трансвагінальної пункції кісти та аспірації ії вмісту під контролем трансвагінального УзД, введення в капсулу кісти 95 \% розчину етанолу.

Результати. Ужінок з безпліддям на фоні ендометріозу, яким призначали прегравідарну підготовку комплексним вітамінним препаратом з інозитолом та вітаміном D3 та проводили склеротерапію, встановлено вірогідно нижчий рівень АМГ (на 12,90\%) та прогестерону (на 9,84 \%) і вірогідно вищий рівень ФСГ (на 14,47\%), ЛГ (на 21,14 \%) та естрадіолу (на 35,55 \%) відносно групи порівняння. При цьому встановлено вірогідно нижчі показники ФСГ (на 21,98 \%), ЛГ (на 32,89 \%) та естрадіолу (на 32,23 \%) проти їх значень до проведення склеротерапії.

Висновки. У кожному конкретному випадку лікування має бути індивідуальним, повністю враховувати всі клінічні фактори, а також вплив захворювання та ефект лікування на якість життя жінки. Проведення склеротерапії із застосуванням прегравідарної підготовки комплексним вітамінним препаратом з інозитолом та вітаміном DЗ у жінок з ендометріоз-асоційованим безпліддям має позитивний вплив на гормональний фон.

КЛЮЧОВІ СЛОВА: безпліддя; ендометріоз; гормони; склеротерапія; інозитом; вітамін D3.

\section{Information about the authors}

Kulyk I.I. - PhD student, Department of Obstetrics and Gynecology, I. Horbachevsky Ternopil National Medical University, Ternopil, Ukraine.

ORCID: https://orcid.org/0000-0003-3766-0259. E-mail: kylyk_iryna1@ukr.net

Khmil S.V. - Professor of the Department of Obstetrics and Gynecology, I. Horbachevsky Ternopil National Medical University, Ternopil, Ukraine.

ORCID: https://orcid.org/0000-0003-0892-9861.E-mail: klinika_khmil@ukr.net

\section{References}

1. Abbas S, Ihle P, Koster I, Schubert I. Prevalence and incidence of diagnosed endometriosis and risk of endometriosis in patients with endometriosisrelated symptoms: findings from a statutory health insurance-based cohort in Germany. Eur J Obstet Gynecol Reprod Biol 2012;160:79-83.

2. Giudice LC. Clinical Practice: Endometriosis. N Engl J Med 2010; 362: 2389-98.

DOI: https://doi.org/10.1056/NEJMcp1000274
3. Bulun SE. Endometriosis. N Engl J Med 2009;360(3): 268-79.

DOI: https://doi.org/10.1056/NEJMra0804690

4. Shestakova IG, Ipastova ID. [Endometriosis: a new consensus - new solutions: Global consensus on the management of patients with endometriosis as a first step towards the creation of industry standards: News bulletin]. Moscow: Status Praesens, 2014; 16 p. (In Russian). 
5. Shcherbyna NA, Demidenko DI, Demidenko AD. [Melatonin's tocolytic activity in threatening preterm birth]. Emergency Medicine. 2014;5:100-102. (In Russian).

6. Borham MM. Comparison between omentoplasty and partial cystectomy and drainage (PCD) techenques in surgical management of hydatid cysts liver in endemic area (Yemen). J. Egypt. Soc. Parasitol. (JESP) 2014; 44(1):145-50.

DOI: https://doi.org/10.12816/0006454

7. Shakiba K, Bena JF, M McGill K. Surgical treatment of endometriosis: a 7-year follow-up on the requirement for further surgery. Obstetrics and Gynecology. 2008;111(6):1285-92.

https://doi.org/10.1097/AOG.0b013e3181758ec6

8. Khamoshina MB, Vakhabova MI, Kalinina EA. [Pharmacotherapy of endometriosis: opportunities and perspectives]. Meditsnskyi Sovet. 2013;8: 23-7. (In Russian).

9. Matsuzaki S, Houlle C, Darcha C. Analysis of risk factors for the removal of normal ovarian tissue during laparoscopic cystectomy for ovarian endometriosis. Human Reproduction. 2009; 24(6):1402-06.

DOI: https://doi.org/10.1093/humrep/dep043

10. Singh AK, Chattopadhyay R, Chakravarty B, Chaudhury K. Markers of oxidative stress in follicular fluid of women with endometriosis and tubal infertility undergoing IVF. Reprod Toxicol. 2013; 42:116-24. 08.005

DOI: https://doi.org/10.1016/j.reprotox.2013.

11. Augoulea A, Mastorakos G, Lambrinoudaki I, Christodoulakos G, Creatsas G. The role of the oxidative-stress in the endometriosis-related infertility. Gynecol Endocrinol.2009; 25: 75-81. 01.0075

DOI: https://doi.org/10.3917/eres.strei.2009.

12. Rubod C, Jean Dit Gautier E, Yazbeck C. Surgical management of endometrioma: Different alternatives in term of pain, fertility and recurrence. CNGOF-HAS Endometriosis Guidelines. Gynecol Obstet Fertil Senol. 2018 Mar;46(3):278-89.

13. Miquel L, Preaubert L, Gnisci A, Netter A, Courbiere B, Agostini. Transvaginal ethanol sclerotherapy for an endometrioma in 10 steps. Fertility and Sterility. 2020.0ct;115(1):259-64.

DOI: https://doi.org/10.1016/j.fertnstert. 2020.08.1422

14. Gatta G, Parlato V, Di Grezia G, Porto A, Cappabianca S, Grassi R. Ultrasound-guided aspi- ration and ethanol sclerotherapy for treating endometrial cysts. Radiol Med.Torino. 2010 Dec;115(8): 1330-9.

DOI: https://doi.org/10.1007/s11547-010-0586-0 15. Aflatoonian A, Rahmani E, Rahsepar M. Assessing the efficacy of aspiration and ethanol injection in recurrent endometrioma before IVF cycle: A randomized clinical trial. Iran J Reprod Med. 2013 Mar;11(3):179-84.

16. Fisch JD, Sher G. Sclerotherapy with $5 \%$ tetracycline is a simple alternative to potentially complex surgical treatment of ovarian endometriomas before in vitro fertilization. Fertil Steril. 2004;82(2):437-41.

DOI: https://doi.org/10.1016/j.fertnstert.2004. 01.031

17. Tsoumpou I, Kyrgiou M, Gelbaya TA, Nardo LG. The effect of surgical treatment for endometrioma on in vitro fertilization outcomes: a systematic review and meta-analysis. Fertil Steril. 2009;92(1):75-87.

DOI: https://doi.org/10.1016/j.fertnstert.2008. 05.049

18. André GM, Vilarino FL, Christofolini DM, Bianco B, Barbosa CP. Aspiration and ethanol sclerotherapy to treat recurrent ovarian endometriomas prior to in vitro fertilization-a pilot study. Einstein (Sao Paulo). 2011 Dec;9(4):494-8.

DOI: https://doi.org/10.1590/s1679-45082011ao2081

19. Wang XT, Meng B, Liu JF, Jin FX and Xu H. The influences of ultrasound guided radiofrequency ablation assisted by polyol on fibroid volume and endocrine function among patients with uterine fibroid. Modern Practical Medicine 2018; 30: 1425-28. https://doi.org/10.1093/rfs/hhx014

20. Alborzi S, Namavar Jahromi B, Ahmadbeigi M. Recovery Rate of Patients with Recurrent Ovarian Endometriomas Using Sclerotherapy with 95\% Ethanol. Journal of Obstetrics, Gynecology and Cancer Research (JOGCR). 2018 Sep 10;3(3):105-10.

DOI: https://doi.org/10.1002/epi4.12285

21. Khmil SV, Kulyk II, Mykula RP. [Antioxidant therapy in women with infertility caused by endometriosis]. Bulletin of social hygiene and health care organization. 2018; 4 (78):56-63 (In Ukrainian).

DOI: https://doi.org/10.11603/1681-2786.2018. 4.10031

22. Tsysar $Y v$, Andriets OA. [The influence of pathology of thyroid gland on menstrual function in girls of pubertal age]. Bukovinian Medical Bulletin. 2011;15(2):130-4. (In Ukrainian).

Received 30 Oct 2020; revised 26 Nov 2020; accepted 02 Dec 2020

This is open access article distributed under the Creative Commons Attribution License, which permits unrestricted use, distribution, and reproduction in any medium, provided the original work is properly cited. 